\title{
Agro-Industrial Waste Materials as Substrates for the Production of Poly(3-Hydroxybutyric Acid)
}

\author{
Artun Sukan, Ipsita Roy, Tajalli Keshavarz \\ Department of Molecular and Applied Biotechnology, Faculty of Science and Technology, University of \\ Westminster, London, UK \\ Email: T.Keshavarz@westminster.ac.uk
}

Received 19 August 2014; revised 16 September 2014; accepted 22 October 2014

Copyright (C) 2014 by authors and Scientific Research Publishing Inc.

This work is licensed under the Creative Commons Attribution International License (CC BY). http://creativecommons.org/licenses/by/4.0/

(c) (i) Open Access

\begin{abstract}
Accumulation of recalcitrant plastics in the environment has become a world-wide problem in today's societies. Rapid depletion of natural resources for synthetic plastics along with environmental concerns has directed research towards finding alternatives to petroleum-based polymers. Poly (3-hydroxybutyric acid) $\mathrm{P}(3 \mathrm{HB})$, as one of these alternatives, have attracted much attention in recent years due to their varied mechanical properties, biocompatibility and biodegradability. The aim of this study was to identify an agro-industrial waste resource economically suitable for large-scale production of $\mathrm{P}(3 \mathrm{HB})$, to optimize the production using Response Surface Methodology in small-scale and subsequently, to test the production in a continuously stirred tank reactor. Among a range of agro-industrial waste, orange peel was selected as the most suitable for $\mathrm{P}(3 \mathrm{HB})$ production. $\mathrm{P}(3 \mathrm{HB})$ concentration of $1.24 \mathrm{~g} \mathrm{P}(3 \mathrm{HB}) / \mathrm{L}$ culture broth with $41 \% \mathrm{P}(3 \mathrm{HB}) / \mathrm{dcw}$ yield was obtained using orange peel as the sole carbon source in optimized medium with a modified strain of Bacillus subtilis (B. subtilis OK2).
\end{abstract}

\section{Keywords}

Agro-Industrial Wastes, CCD, STR, Orangepeel, Optimisation, Poly(3-Hyrdroxybutyric Acid)

\section{Introduction}

Plastics have a number of desirable properties over conventional materials. These include low density, strength, durability and resistance to degradation [1]. However, accumulation of recalcitrant plastics in the environment has become a world-wide problem. In 2005, 18 million barrels of crude oil-equivalent were used to manufacture

How to cite this paper: Sukan, A., Roy, I. and Keshavarz, T. (2014) Agro-Industrial Waste Materials as Substrates for the Production of Poly(3-Hydroxybutyric Acid). Journal of Biomaterials and Nanobiotechnology, 5, 229-240. 
2 million polyethylene terephthalate (PET) bottles [2]. Along with the environmental problems, rapid depletion of natural resources, is forcing research to focus on alternatives to petroleum-based plastics.

Polyhydroxyalkanoates (PHAs), as one of these alternatives, have attracted much attention in recent years due to their varied mechanical properties, biocompatibility and biodegradability [3]. PHAs are a family of linear polyesters of 3, 4, 5 \& 6-hydroxyacids. They are water insoluble and have thermoplastic and elastomeric properties. They are synthesised and stored intracellularly by a wide variety of bacteria such as, Bacillus sp., Pseudomonas $s p$. , Azobacterium and many recombinant strains through the fermentation of sugars, lipids, alkanes, alkenes and alkanoic acids, in the presence of excess carbon while another essential nutrient, such as nitrogen or phosphorus, is limiting [4]-[8] (Figure 1). In addition, the composition and the concentration of the polymer in the cell is strongly dependent on the C:N ratio of the media [9]-[11]. Therefore, it is important to monitor and adjust the $\mathrm{C}: \mathrm{N}$ ratio of the medium used in PHA production.

There are two main groups of PHAs, namely, short chain length (scl)-PHAs and medium chain length (mcl)PHAs. Scl-PHAs consist of 3-5 carbon atoms and mcl-PHAs contain 6-14 carbon atoms [4]-[8]. They are also identified as homo-polymers and hetero-polymers depending on whether one or more than one type of hydroxyalkanoate units are found as monomer units in the polymer [12]. Scl-PHAs have high crystallinity with a melting point of $180^{\circ} \mathrm{C}$ and an elongation to break of $5 \%$. However mcl-PHAs and their copolymers have low crystallinity (20\% - 40\%) and do not break easily (extension to break of 300\% - 450\%). They behave as elastomers and their composition can be manipulated for a range of applications [13].

The physical and chemical properties of PHAs are affected by the monomer composition. The monomer composition of the polymer depends on type of micro-organism, media ingredients, fermentation conditions, modes of fermentation and recovery methods [7].

The high costs of raw material and relatively low conversion rates are the two main problems in large-scale industrial production of PHAs [14]. Studies are targeted to bring down the cost of the polymer to 2.20 - 0.99 $\$ / \mathrm{kg}$ range or lower in order to compete with the petroleum-derived polymers [5]. Process economics have revealed that the use of inexpensive and renewable carbon substrates as PHA carbon feedstock can result in as much as $40 \%$ - 50\% reduction in the overall production cost [15]. Extensive research has been conducted to identify cheap sources for the fermentation media. A number of studies are made for production of PHAs using different media compositions. These include, molasses [6] [16]-[18] corn steep liquor [19], whey [20] [21], wheat and rice bran [22] [23], starch and starchy wastewaters [24]-[27], effluents from olive mill and palm oil mill [28]-[30], activated sludge [31] [32], glycerol liquid phase (GLP) from the biodiesel production process [33] waste frying oil [34], wheat hydrolysate [35] and bagasse hydrolysates [36]. Although utilization of several agro-industrial wastes have been reported for various bioprocess applications, the full potential of the whole range is yet to be investigated. This paper attempts to extend the use of agro-industrial wastes for bio-polymer production.

The aim of this study was to identify a suitable agro-industrial waste source economically suitable for large scale production of $\mathrm{P}(3 \mathrm{HB})$, a scl-PHA, to optimize the production using Response Surface Methodology and to test the production in a stirred tank reactor (STR).

\section{Materials and Methods}

\subsection{Chemicals and Culture Media}

All the chemicals used for analyses were HPLC grade and obtained from Merck. The defined culture medium [8] was composed of $20 \mathrm{~g} / \mathrm{L}$ glucose, $2.5 \mathrm{~g} / \mathrm{L}$ yeast extract, $3 \mathrm{~g} / \mathrm{L} \mathrm{KCl}$ and $5 \mathrm{~g} / \mathrm{L}\left(\mathrm{NH}_{4}\right)_{2} \mathrm{SO}_{4}$. All chemicals were obtained from Sigma-Aldrich Company Ltd (Dorset, UK).

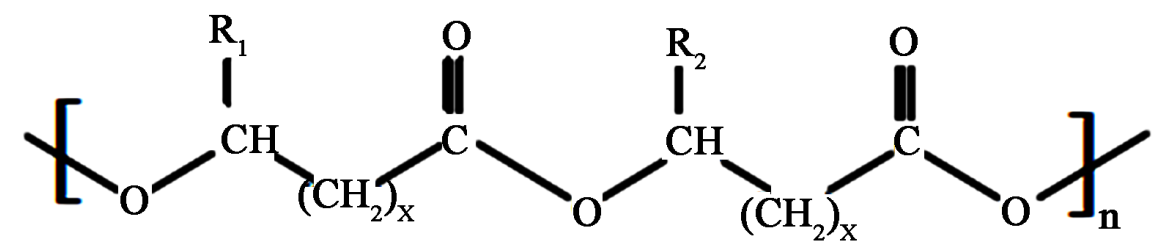

Figure 1. The general structure of Polyhydroxyalkanoates $(n=100-30,000)$ [3]. 


\subsection{Bacterial Strain}

The recombinant strain, B. subtilis OK2 was gift from Prof Fujio Kawamura, Department of Life Sciences, Rikkyo University, Japan. The strain was chosen as a model for the experiments, due to its potential as a multiple producer for industrially useful bio-products. In this paper only the $\mathrm{P}(3 \mathrm{HB})$ production capability of the strain was exploited. Stock cultures were grown at $30^{\circ} \mathrm{C}$ in nutrient broth and maintained at $4^{\circ} \mathrm{C}$ on nutrient agar.

\subsection{Equipment}

The Spectrophotometer used in this study was Jenway 6503 UV-spectrophotometer, freeze dryer was Thermo Savant ModulyoD, the centrifuge was Denley BS400, the orbital shaker was Innova 4430 incubator shaker, Kjeldahl apparatus was Gerhardt, and the fermenter was Electrolab FerMac310/60 fermentation system equipped with automated control.

\subsection{Waste Material and Pre-Treatment}

Four different agro-industrial waste materials namely, rapeseed cake (RS), orange peel (OP), wheat bran (WB), Spirulina powder (S), and 4 different pre-treatment methods were tested for their suitability for production of $\mathrm{P}(3 \mathrm{HB})$. In order to avoid high downstream processing costs emerging from high solid contents of these waste materials, four different pre-treatment methods were tested. To begin with, all waste materials were suspended in water at a concentration of $10 \mathrm{~g} / \mathrm{L}$. One group was treated with microwave at $800 \mathrm{~W}$ for 2 min (Coded as D). The other three were subjected to mild acid (Coded as A), mild alkaline (Coded as B) and water suspension (Coded as C). All three were incubated at $70^{\circ} \mathrm{C}$ and $100 \mathrm{rpm}$ for 2 hours. The $\mathrm{pH}$ of the acid and the alkali treatments were set at $\mathrm{pH} 3.5$ and 10.5 respectively. Following the pre-treatments, the media were filtered and sterilized at $110^{\circ} \mathrm{C}$ for 10 min prior to inoculation.

\section{5. $\mathrm{P}(3 \mathrm{HB})$ Extraction}

For the extraction of $\mathrm{P}(3 \mathrm{HB})$, the cells were harvested by centrifugation at $5000 \mathrm{~g}$ and then lyophilized. $\mathrm{P}(3 \mathrm{HB})$ was extracted by treating 1 gram of freeze-dried cells with a mixture containing $50 \mathrm{ml}$ of chloroform and $50 \mathrm{ml}$ of a $30 \%$ sodium hypochlorite solution in an orbital shaker at $100 \mathrm{rpm}$, at $37^{\circ} \mathrm{C}$ for 1 hour. The mixture obtained was then centrifuged at $4500 \mathrm{rpm}$ for $10 \mathrm{~min}$. This resulted in three separate phases. $\mathrm{P}(3 \mathrm{HB})$ was recovered from the bottom, i.e. chloroform phase, by precipitation using 10 volumes of ice-cold methanol [8].

\subsection{Analytical Methods}

\subsection{1. $\mathrm{P}(3 \mathrm{HB})$ Quantification}

For the identification of $\mathrm{P}(3 \mathrm{HB})$ content, a slight modification of the crotonic acid method of Law and Slepecky [37] was applied. $200 \mu \mathrm{l}$ of the chloroform phase obtained from the extraction stage was transferred to a clean tube, air dried and mixed with $5 \mathrm{ml}$ concentrated sulphuric acid. The tube was incubated in $80^{\circ} \mathrm{C}$ water bath for $1 \mathrm{~h}$ while mixed vigorously before incubation, half-way through and after incubation. The absorbance was measured at $235 \mathrm{~nm}$ and the concentration was calculated using a calibration curve specifically drawn for this system

\subsubsection{Dry Cell Weight Determination}

For the dry cell weight (dcw) determination, depending on the experiment, known volumes of either all or part of the cultures were taken and centrifuged at $4200 \mathrm{~g}$ for 15 mins to separate the cells. The cell paste was washed with distilled water and freeze-dried before weighing.

\subsubsection{Total Sugar and Nitrogen Content Measurements}

Phenol-sulphuric acid method was applied for the determination of totalsugar content [38]. Total nitrogen analysis was carried out using the Kjeldahl method [39] at Ege University, Department of Bioengineering, Turkey.

\subsection{Experimental Design}

A central composite design (CCD) was applied using Design-Expert 6.0 (trial version), with three variables and 
five levels (Table 1) in order to explore the effect of variables on the culture response within the region of investigation. Waste material concentration, citrate and yeast extract concentrations were chosen as the most effective independent variables based on our preliminary experiments (data not shown) and the literature [13]. A total number of 18 experiments were carried out using the three variables. To evaluate pure error, the eighteen experiments were augmented with four replications at the centre point marked as 0 (Table 1). The experiments were conducted in shaken flasks at $30^{\circ} \mathrm{C}$ and $250 \mathrm{rpm}$. $\mathrm{P}(3 \mathrm{HB})$ concentration was taken as the response. Experiments were performed according to the experimental design matrix given on Table 1, within the ranges indicated.

The matrix for the three variables was varied at five levels $(-\alpha,-1,0,+1,+\alpha)$. The higher level of variable was designed as " +1 ", the lower level was designed as " -1 ", centre point was designed as "0" and star points were designed as " $-\alpha$ " and " $+\alpha$ ". In the optimization process the response can be related to the chosen variables by linear or quadratic models. A quadratic model is given as:

$$
y=\beta_{0}+\sum_{i=1}^{3} \beta_{i i} X_{i}+\sum_{i=1}^{3} \beta_{i i} X_{i}^{2}+\sum_{i=1}^{3} \sum_{j=i+1}^{3} \beta_{i j} X_{i} X_{j}+e
$$

where $y$ is the response, $\beta_{0}$ the constant coefficient, $\mathrm{X}_{i}(I=1-3)$ are non-coded variables, $\beta_{i} \mathrm{~S}$ are the linear, and $\beta_{i i} \mathrm{~s}$ are the quadratic, and $\beta_{i j} \mathrm{~s}$ are the second-order interaction coefficients. The parameters in our study were coded by letters (e.g. A, B, C) rather than $X_{i}$ for clarification. Data were processed for Equation (1) using Design-Expert 6.0 program including ANOVA to obtain the interaction between the process variables and the response. The quality of the fit of the polynomial model was expressed by the coefficient of determination $\mathrm{R}^{2}$.

\subsection{STR Experiment}

Based on the results obtained from the central composite design, the best medium was tested under controlled conditions of a stirred tank reactor (STR) in batch mode. Two fermentations (culture and test) were carried out in parallel in 0.5L batch reactors equipped with turbine type impellors. The conditions were kept the same for both the control and the test at $30^{\circ} \mathrm{C}, 400 \mathrm{rpm}$ agitation and $1 \mathrm{vvm}$ aeration. During the fermentation, $\mathrm{pH}$, temperature and dissolved oxygen tension (\%DOT) were monitored and $12 \mathrm{ml}$ samples were taken against time. Optical density, P(3HB) concentration, dcw and total sugar content were determined. The results obtained with the optimized medium were compared with the results obtained with the defined medium.

\section{Results and Discussion}

\subsection{Waste Material Screening}

Four different agro-industrial waste materials namely, rapeseed cake (RS), orange peel (OP), wheat bran (WB), Spirulina powder (S), and 4 different pre-treatment methods were tested for their suitability for production of $\mathrm{P}(3 \mathrm{HB})$. Among all the waste materials tested, the best production was observed with the water treated orange peel (Figure 2). The $\mathrm{P}(3 \mathrm{HB}$ ) values obtained were low in all waste materials but this was due to the low nutrient content of the waste material and the $\mathrm{P}(3 \mathrm{HB})$ production ability of $B$. subtilis OK2. No additional nutrients were added into the media prepared by the waste materials. This was deliberately done to investigate the yields obtained by the inherent components of the waste materials as the sole ingredients for $\mathrm{P}(3 \mathrm{HB})$ production. The best production was obtained when orange peel was treated only with distilled water (2.5 mg P(3HB)). The second best result was obtained with acid treatment (1.4 mg P(3HB)). Water and alkaline treatments of Spirulina were also high relative to the other waste materials (1.2 and 1.16 respectively).

Anderson and Dawes [13], and Kessler and Witholt [40] reported that citric acid promotes PHA formation. Ersus and Cam [41] investigated the organic acid content of Citrus aurantium peels using HPLC. The predomi-

Table 1. Experimental design matrix showing five levels for CCD.

\begin{tabular}{ccccccc}
\hline Parameter & Code & $-\alpha$ & -1 & 0 & +1 & $+\alpha$ \\
\hline Orange Peel (OP) & A & 30.00 & 40.57 & 55.00 & 69.43 & 80.00 \\
Yeast Extract (YE) & B & 1.00 & 1.63 & 2.50 & 3.37 & 4.00 \\
Citrate (Cit) & C & 0.00 & 0.42 & 1.00 & 1.58 & 2.00 \\
\hline
\end{tabular}




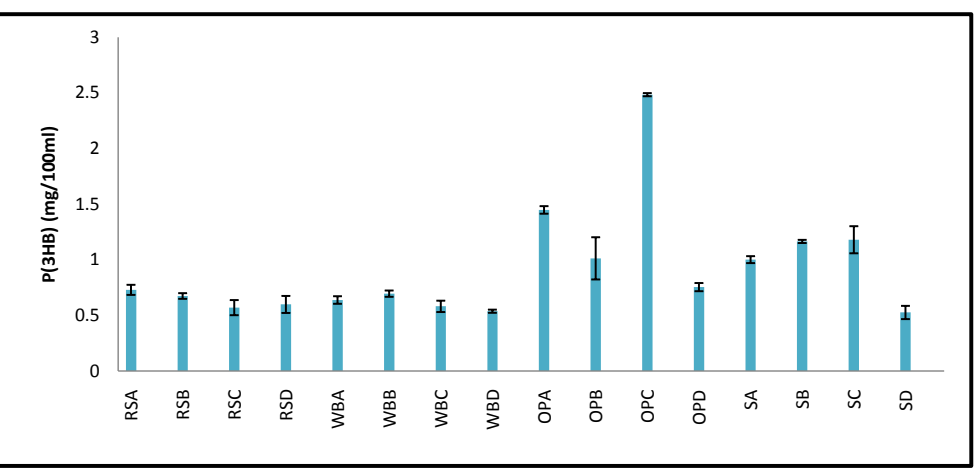

Figure 2. Results showing the $\mathrm{P}(3 \mathrm{HB})$ amounts obtained from various waste materials and pre-treatments; RS: rapeseed cake, OP: orange peel, WB: wheat bran, S: Spirulina powder; A: Acid treatment, B: Alkaline Treatment, C: Water treatment, D: Microwave treatment.

nant organic acids in freshly prepared peel samples were found to be oxalic acid ( $257.5 \mathrm{mg} / 100 \mathrm{~g}$ peel), ascorbic acid (117.6 mg/100 g peel) and quinic acid ( $98.5 \mathrm{mg} / 100 \mathrm{~g}$ peel), but malic acid and citric acid were not detected. This indicated that, promotion of $\mathrm{P}(3 \mathrm{HB})$ production is affected not by citric acid but by some other ingredient present in orange peel. When different pre-treatments were compared orange peel treated by water showed the highest $\mathrm{P}(3 \mathrm{HB})$ production, although $\% \mathrm{P}(3 \mathrm{HB}) / \mathrm{dcw}$ values for acid and water treatments were very close to each other. According to Ververis et al. [42] orange peel contains $13.6 \%$ cellulose, $6.1 \%$ hemicellulose and $2.1 \%$ lignin within its dry weight. As a pre-treatment method, hot water treatment mainly removes hemicelluloses. Liquid soluble oligosaccharides are dissolved and separated from insoluble cellulosics and lignin fractions of solid agricultural material. In mild acid treatment, all of the hemi-cellulosic content dissolves in water and the treatment helps hydrolysing lignocellulose content to fermentable sugars. Mild alkaline treatment mainly removes lignin and part of the hemicellulose from the solid content. $\mathrm{NaOH}$ treatment has been referred to as the most effective delignification method for agricultural wastes [43] and is also known to be an effective method in breaking ester bonds between lignin, hemicellulose and cellulose. Release of lignin into the liquid medium can be considered as one of the reasons why alkaline treatment does not promote $\mathrm{P}(3 \mathrm{HB})$ production. Phenolic compounds from lignin structures interfere with the production.

Among the pre-treated orange peel media, microwave treatment showed the lowest $\mathrm{P}(3 \mathrm{HB})$ production. Microwave treatment mainly affects lignin and lignocellulose contents. The cellulose component of lignocellulose can be degraded into fragile fibres and low molecular weight oligosaccharides. However this is only observed in the presence of lignin. The fact that orange peel contains only $2 \%$ lignin may explain why microwave treatment was not as effective as other treatments. In addition, microwave treatment is more effective in air than in solution [43].

As a result of this preliminary screening, orange peel treated with distilled water was selected for further experiments. Up to date, apart from a patent by de Aragao et al. [44], there are no reports on orange peel as a potential substrate for $\mathrm{P}(3 \mathrm{HB})$ production. In the patent, a new pre-treatment method is described for citrus residues in order to be used as a carbon source for PHA production [44]. The invention involves the use of citric residues generated by fruit juice industry to produce citric molasses to be utilised as fermentation medium. However the pre-treatment described, involving a series of physical and chemical processes, is costly compared to the pre-treatment method suggested in this study.

\subsection{Nitrogen Content of Orange Peel}

After waste material selection, nitrogen content of orange peel was analysed in order to determine the requirement for nitrogen supplementation. The nitrogen content was determined using a Kjeldahl apparatus. The results shown in Table 2, indicates that nitrogen content of orange peel is poor and in order to be utilized as substrate for $\mathrm{P}(3 \mathrm{HB})$ production it needs to be supplemented with a suitable nitrogen source. For this study, yeast extract was selected as a good nitrogen containing source with trace elements.

In all subsequent experiments, orange peel and yeast extract were used as carbon and nitrogen sources respectively. 
Table 2. Nitrogen content of Orange peel and yeast extract.

\begin{tabular}{cc}
\hline Sample $(\mathbf{1} \mathbf{g})$ & Nitrogen Percentage (\%) \\
\hline Dry orange peel & 7.56 \\
Yeast extract & 63.51 \\
\hline
\end{tabular}

\subsection{Central Composite Design}

As was mentioned in the methods section, the parameters, subject to statistical optimization, were selected through preliminary experiments. The waste material content (Orange peel in this case) needed to be supplemented with a suitable nitrogen source due to its insufficient nitrogen content (Table 2).

The following model (Equation (2)) was presented and the levels of each parameter were optimized. The model was significant with all three parameters tested $(\mathrm{p}<0.05)$ (Table 3 ). The $\mathrm{R}^{2}$ of the model obtained was 0.954 .

$$
\begin{aligned}
\operatorname{PHB}(\mathrm{g} / L)= & 0.12+(0.08 * A)-(1.11 * B) \\
& +(0.063 * C)-(0.022 * A B)+(0.06 * A C) \\
& -(0.023 * B C)+\left(0.03 * A^{2}\right)+\left(0.049 * B^{2}\right)+\left(0.03 * C^{2}\right)
\end{aligned}
$$

The coefficients of $A$ and $C$ were positive, indicating that the contribution of those parameters was positive for $\mathrm{P}(3 \mathrm{HB})$ production, which in this case are orange peel and citrate. Whereas, variable $\mathrm{B}$, which is yeast extract in this model, has a negative coefficient indicating that, contribution of $\mathrm{B}$ negatively affects the $\mathrm{P}(3 \mathrm{HB})$ production. PHAs are mostly produced under limiting nutrient conditions and in the presence of excess carbon source [15]. In this case, nitrogen was supplied to the medium as the limiting ingredient of yeast extract. The model shows that in the presence of low nitrogen source more $\mathrm{P}(3 \mathrm{HB})$ will be produced. This result is in agreement with the literature [8] [15].

On the other hand the quadratic effect of the nitrogen source showed a positive effect on $\mathrm{P}(3 \mathrm{HB})$ production (coefficient of $\mathrm{B}^{2}$ ). Although, the contribution was significantly lower compared to the linear effect, this indicates that a small amount of nitrogen would actually promote $\mathrm{P}(3 \mathrm{HB})$ production. This argument was validated with the experiments presented in this study as well as previous studies reported by other researchers. Page [45] studied production of $\mathrm{P}(3 \mathrm{HB})$ by Azotobacter vinelandii, and reported that, the $\mathrm{P}(3 \mathrm{HB})$ production was promoted by the addition of trace amounts of complex nitrogen sources. Similarly Lee and Chang [46] studied the effect of complex nitrogen sources on the synthesis of $\mathrm{P}(3 \mathrm{HB})$ by recombinant $E$. coli and reported that corn steep liquor which did not enhance $\mathrm{P}(3 \mathrm{HB})$ synthesis significantly, could promote $\mathrm{P}(3 \mathrm{HB})$ production when supplemented with yeast extract.

The other parameter, A, has a positive coefficient. This indicates that excess carbon needs to be present in the medium for high $\mathrm{P}(3 \mathrm{HB})$ production. Again this statement is very well in agreement with the values stated by other researchers [7] [8] [15].

The last parameter investigated was citrate, presented as $\mathrm{C}$. The parameter $\mathrm{C}$ had a positive coefficient indicating that the presence of citrate affects the $\mathrm{P}(3 \mathrm{HB})$ production positively. This has been reported through the production pathways of PHAs in Bacillus sp [13] [40] [47]. PHAs are produced from acetyl-CoA. The addition of citrate blocks the TCA cycle, shifting most of the acetyl-CoA generated through glycolysis towards PHA synthesis. This results in the utilisation of the available sugars for the production of PHAs while altering the metabolism and inhibiting cell growth. This negative effect was not recognized by the program due to the narrow range selected for screening since high concentration of citrate was found to inhibit the cellular growth (unpublished results). The model can also be interpreted by looking at the values of the coefficients. The highest value is 1.11 (coefficient of $\mathrm{B}$ ). This indicates that the negative contribution of the yeast extract is more dominant compared to other variables, a small change in this variable will make a bigger difference with respect to the others. The second most important variable is orange peel (variable A). The positive contribution of carbon source is more significant compared to citrate (variable C). When point prediction was carried out in order to maximize $\mathrm{P}(3 \mathrm{HB})$ production within the current culture conditions, the levels of orange peel, yeast extract and citrate were found to be $69.39 \mathrm{~g} / \mathrm{L}, 1.63 \mathrm{~g} / \mathrm{L}, 1.58 \mathrm{~g} / \mathrm{L}$ respectively (Table 4).

According to the optimum point predicted by the program, $0.589 \mathrm{~g} \mathrm{P}(3 \mathrm{HB}) / \mathrm{L}$ culture broth is achievable us- 
Table 3. ANOVA results for CCD.

\begin{tabular}{cccccc}
\hline & Sum of Squares & df & Mean Square & F Value & p-value \\
\hline Model & 0.86 & 9 & 0.043 & 18.447 & 0.0002 \\
A-OP & 0.19 & 1 & 0.088 & 37.555 & 0.0003 \\
B-YE & 0.36 & 1 & 0.163 & 69.908 & $<0.0001$ \\
C-Cit & 0.12 & 1 & 0.056 & 23.822 & 0.0012 \\
AB & 0.01 & 1 & 0.004 & 1.617 & 0.2393 \\
AC & 0.06 & 1 & 0.029 & 12.386 & 0.0079 \\
BC & 0.01 & 1 & 0.004 & 1.843 & 0.2116 \\
$\mathbf{A}^{2}$ & 0.03 & 1 & 0.015 & 6.599 & 0.0332 \\
$\mathbf{B}^{2}$ & 0.08 & 1 & 0.034 & 14.674 & 0.0050 \\
$\mathbf{C}^{2}$ & 003 & 1 & 0.012 & 5.308 & 0.0502 \\
Residual & 0.04 & 8 & 0.002 & & 0.5627 \\
Lack of Fit & 0.03 & 5 & 0.002 & 0.926 & 0.954 \\
Pure Error & 0.02 & 3 & 0.002 & & $\mathrm{R}^{2}$ \\
Std. Error & 0.072 & & & & \\
\hline
\end{tabular}

Table 4. Optimisation result and statistical analysis and confidence levels.

\begin{tabular}{ccccc}
\hline OP $(\mathrm{g} / \mathrm{L})$ & YE $(\mathrm{g} / \mathrm{L})$ & Citrate $(\mathrm{g} / \mathrm{L})$ & $\mathbf{P}(\mathbf{3 H B})(\mathrm{g} / \mathrm{L})$ & Desirability \\
\hline 69.39 & 1.63 & 1.58 & 0.589 & 0.935 \\
Response & Prediction & SE Mean & $\mathbf{9 5 \% ~ C I ~ l o w ~}$ & $\mathbf{9 5 \% ~ C I ~ h i g h ~}$ \\
P(3HB) (g/L) & 0.589 & 0.039 & 0.498 & 0.697 \\
\hline
\end{tabular}

ing the suggested levels (Table 4). In order to validate the predicted point, a triplicate validation experiment was carried out. The levels obtained from all flasks were within the confidence interval and the average production was $0.61 \mathrm{~g} \mathrm{P}(3 \mathrm{HB}) / \mathrm{L}$ culture broth with $30 \% \mathrm{P}(3 \mathrm{HB}) / \mathrm{cdw}$. These values are within the range of the ones reported in the literature using defined media. Yields of 58.6\% PHA/cdw [48] and 32.9\% P(3HB)/cdw [49] were obtained using glucose as carbon source and Bacillus megaterium and Bacillus sp. Thirumala et al. [50] investigated the effects of different sugars on $\mathrm{P}(3 \mathrm{HB})$ production using Bacillus sp. They reported yields ranging between $24 \% \mathrm{P}(3 \mathrm{HB}) / \mathrm{dcw}$ (using mannitol as carbon source) and $70 \% \mathrm{P}(3 \mathrm{HB}) / \mathrm{dcw}$ (using glucose as carbons source). Very little has been reported using waste materials and Bacillus sp. The main waste materials tested were sugar based such as beet or cane molasses and date syrup. The yields varied from $5.8 \mathrm{~g} \mathrm{P}(3 \mathrm{HB}) / \mathrm{L} \mathrm{to} 0.16 \mathrm{~g}$ $\mathrm{P}(3 \mathrm{HB}) / \mathrm{L}[17]$ [50]-[52].

\subsection{Reactor Experiment}

Based on the validation experiment where the confidence interval and average production was determined, parallel fermentations were carried out in identical $0.5 \mathrm{~L}$ fermenters with a working volume of $0.4 \mathrm{~L}$ using the optimized medium in order to observe the production profile. The fermentations were carried out for three days. Three samples were taken daily from each fermenter and analysed for total carbohydrate, $\mathrm{P}(3 \mathrm{HB})$ content, optical density $\left(\mathrm{OD}_{600}\right)$ and dcw.

The optimized orange peel medium was used for the test fermentation, and a previously optimized medium was used for the control fermentation [8]. The $\mathrm{P}(3 \mathrm{HB})$ obtained from the test fermentation was higher than the control. Using the medium composed of orange peel, a maximum production of $1.24 \mathrm{~g} \mathrm{P}(3 \mathrm{HB}) / \mathrm{L}$ culture broth was observed corresponding to $40 \% \mathrm{P}(3 \mathrm{HB}) / \mathrm{cdw}$ (Figure 3). This was double the amount achieved in shaken 


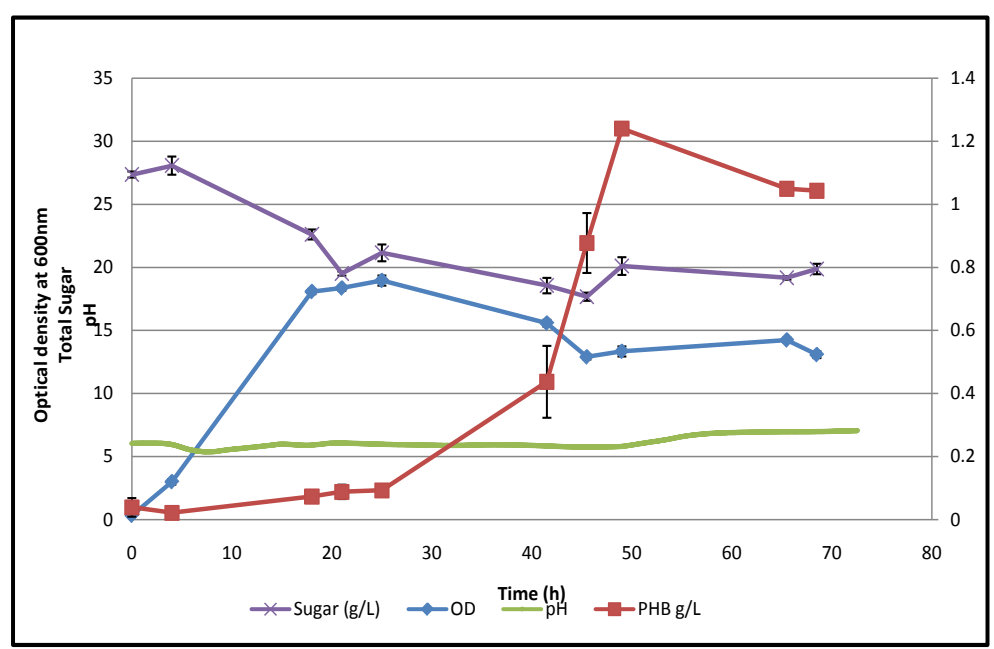

Figure 3. Fermentation profile of $\mathrm{P}(3 \mathrm{HB})$ production using orange peel me$\operatorname{dium}\left(\mathrm{At} ; 30^{\circ} \mathrm{C}, 400 \mathrm{rpm}, 1 \mathrm{vvm}\right)$.

flasks in this study. In the literature the highest production using waste material is reported by Khiyami et al. [51]. They achieved a yield of $68 \mathrm{~g} \mathrm{P}(3 \mathrm{HB}) / \mathrm{L}$ by using $15 \% \mathrm{v} / \mathrm{v}$ date syrup as a carbon source with Bacillus SA at $\mathrm{pH} 7,120 \mathrm{rpm}, 30^{\circ} \mathrm{C}$. Halami [24] investigated a batch fermentation using starch as raw material and reported a production of $0.48 \mathrm{~g} / \mathrm{L}$. Similarly Omar et al. [17] reported $1.5 \mathrm{~g} / \mathrm{L}$ production using $2 \% \mathrm{w} / \mathrm{v}$ date syrup as carbon source and keeping the conditions at $\mathrm{pH} 7,30^{\circ} \mathrm{C}, 100 \mathrm{rpm}, 0.9 \mathrm{vvm}$. In the control fermentation, the maximum production was $1.03 \mathrm{~g} \mathrm{P}(3 \mathrm{HB}) / \mathrm{L}$ culture broth (Figure 4). However, although the $\mathrm{P}(3 \mathrm{HB})$ concentration was lower, the \% dcw $\mathrm{P}(3 \mathrm{HB})$ was higher ( $49 \%$ dcw $\mathrm{P}(3 \mathrm{HB})$ ). This could be due to the early commencement of $\mathrm{P}(3 \mathrm{HB})$ production in the control fermentation (20h). Another reason for this difference could be due to differences in the $\mathrm{pH}$ profiles of the respective fermentations. In the test medium there was citrate present in order to enhance $\mathrm{P}(3 \mathrm{HB})$ production. However, the $\mathrm{pH}$ profile indicates that citrate also acted as a buffer keeping the $\mathrm{pH}$ more or less stable around $\mathrm{pH}$ 6, while in the control, the $\mathrm{pH}$ dropped to 4 , when the culture entered the stationary phase. The rise in $\mathrm{P}(3 \mathrm{HB})$ concentration coincides with this, suggesting that the $\mathrm{pH}$ drop could have had a role in inducing the $\mathrm{P}(3 \mathrm{HB})$ production as well as inhibiting cellular utilisation of the stored $\mathrm{P}(3 \mathrm{HB})$.

The total $\mathrm{P}(3 \mathrm{HB})$ yield was higher with the orange peel substrate, however $\mathrm{P}(3 \mathrm{HB})$ production profile was delayed in comparison to the control, the peaks being observed at $50 \mathrm{~h}$ and $20 \mathrm{~h}$ respectively. In the test fermentation, $\mathrm{P}(3 \mathrm{HB})$ concentration peaked after $50 \mathrm{~h}$ and then it started to drop as $\mathrm{pH}$ started to increase. Although the $\mathrm{OD}_{600}$ profiles of the test and control were different, the stabilisation in OD values was concomitant with an increase in the $\mathrm{pH}$ and $\mathrm{P}(3 \mathrm{HB})$ production.

Despite the different substrates used, the total carbohydrate assay showed similar profiles for both fermentations. A slow decrease in total sugar content was observed concomitant to a slow increase in $\mathrm{P}(3 \mathrm{HB})$ production and a step increase was observed in sugar content when the $\mathrm{P}(3 \mathrm{HB})$ production peaked. Other peaks (unidentified) were observed in both total sugar profiles indicating the possible presence of some other extracellular carbohydrates being simultaneously produced during the fermentation. The profiles indicate that sugar is not used completely during the fermentation. This could be due to the depletion of the nitrogen source in the fermenter, as nitrogen is the key nutrient for cellular growth as well as $\mathrm{P}(3 \mathrm{HB})$ production. Partial utilization of sugar (sucrose), was also reported by Omar et al. [17], where they obtained 25\% dcw P(3HB). In this study the maximum yield was $41 \%$ dcw $\mathrm{P}(3 \mathrm{HB})$ at a concentration of $1.24 \mathrm{~g} \mathrm{P}(3 \mathrm{HB}) / \mathrm{L}$ culture broth.

Although the results are promising for production of PHAs using orange peel, the strain used in this study was not a high producer of PHA. The aim in this study was to study the potential of selected waste material and not to investigate a system for high production of PHAs. Further investigation is needed in order to enhance the productivity and optimize the conditions in the reactor using a high producer strain.

\section{Conclusions}

The total world production of Citrus fruits is over 117 million tons of oranges, lemons, grapefruits and manda- 


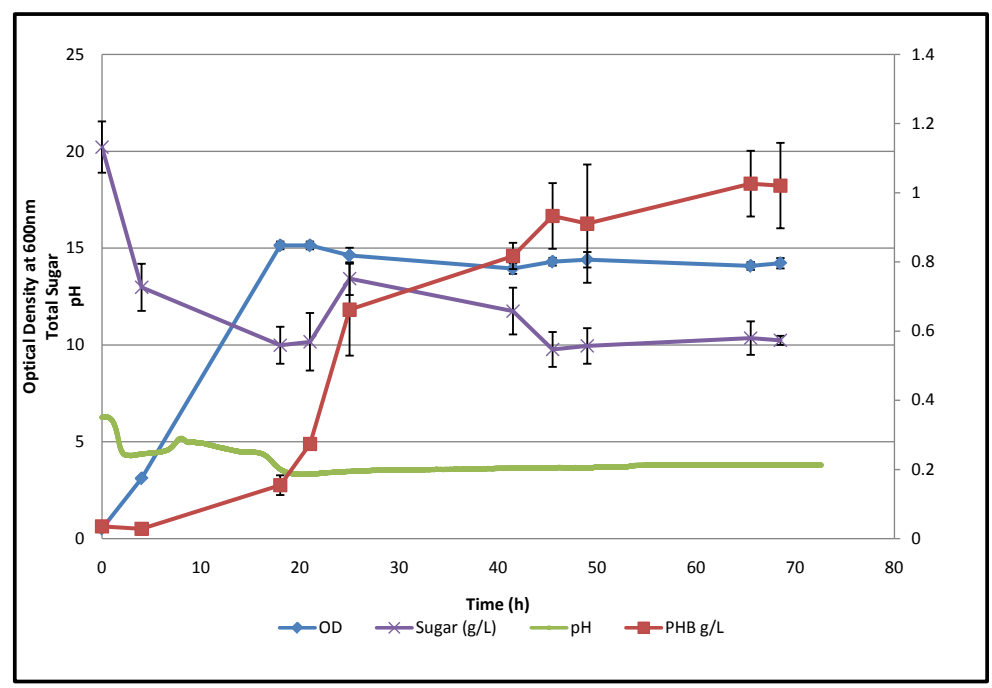

Figure 4. Fermentation profile of $\mathrm{P}(3 \mathrm{HB})$ production using control medium (At; $\left.30^{\circ} \mathrm{C}, 400 \mathrm{rpm}, 1 \mathrm{vvm}\right)$.

rins. One-third of the crop is industrialized, with oranges accounting for approximately $82 \%$ of the total citrus crop [53].

Approximately $60 \%$ of all citrus fruit is consumed domestically; $7 \%$ is used for industrial purposes [54] for the production of mainly fruit juice and jams and confectionary goods. Approximately $50 \%$ of the original whole fruit mass after citrus processing for juice, is converted into waste material at the end of industrial production. $10 \%$ of total production is discarded as waste during picking, packaging and storing.

The solid residues of citrus processing consist primarily of the peel (exterior yellow peel and the interior white spongy peel), membranes and seeds. This raw wet residue contains $76 \%-82 \%$ water. The dry residue consists of approximately $31 \%$ simple sugars (e.g. fructose, glucose and sucrose), $19 \%$ pectin, $12 \%$ cellulose, $12 \%$ hemicellulose, $7 \%$ flavonoids, $4.8 \%$ organic acids, $4.8 \%$ protein, $4.8 \%$ ash, and $4.8 \%$ oil.

However, currently, the residues from such processes are not being valorised. They are either used as animal feed additive or are discarded directly. Citrus waste is highly fermentable due to its carbohydrate content and therefore the current practice of discarding citrus wastes to landfills causes an environmental hazard.

In this study, orange peel was used as a sole carbon source in the medium optimized for $\mathrm{P}(3 \mathrm{HB})$ production with a result of $1.24 \mathrm{~g} \mathrm{P}(3 \mathrm{HB}) / \mathrm{L}$ culture broth. These results clearly show that orange peel which is an abundant and unutilised agro-industrial waste material especially in the Mediterranean, is a very attractive and an economically feasible carbon source for the production of PHAs. Here, we have reported for the first time the production of $\mathrm{P}(3 \mathrm{HB})$ using orange peel as a sole carbon source with a very simple pre-treatment method. Although the strain selected was not a high producer, the results obtained indicated that the presence of orange peel as a medium component promoted $\mathrm{P}(3 \mathrm{HB})$ production significantly. Additional research is continuing to further optimise the production process in the fermenter scale by adjusting the process parameters and scaling up the entire process to be suitable for large scale production. Further research is needed in downstream processing and further industrial strain selection in order to make this process feasible for commercial production.

\section{Acknowledgements}

The authors would like to thank Prof. Fazilet Vardar for permission to access to the facilities of Department of Bioengineering, Ege University, Faculty of Engineering, Izmir, Turkey and ÖzgeAkyüz for her efforts for the determination of the nitrogen content. We would also like to thank Prof Fujio Kawamura, Department of Life Sciences, Rikkyo University, Japan for the gift of the bacterial strain, Bacillus subtilis OK2.

\section{References}

[1] Khanna, S. and Srivastava, A.K. (2005) Recent Advances in Microbial Polyhydroxyalkanoates. Process Biochemistry, 40, 607-619. http://dx.doi.org/10.1016/j.procbio.2004.01.053 
[2] (2010) Eco-Cycle Environmental Facts and Figures to Inspire Action toward Zero Waste. http://www.ecocycle.org/files/pdfs/Eco-CycleEnvironmentalFacts.pdf

[3] Francis, L. (2011) Biosynthesis of Polyhydroxyalkanoates and Their Medical Applications. University of Westminster, London.

[4] Castilho, L.R., Mitchell, D.A. and Freire, D.M.G. (2009) Production of Polyhydroxyalkanoates (PHAs) from Waste Materials and By-Products by Submerged and Solid-State Fermentation. Bioresource Technology, 100, 5996-6009. http://dx.doi.org/10.1016/j.biortech.2009.03.088

[5] Philip, S., Keshavarz, T. and Roy, I. (2007) Polyhydroxyalkanoates: Biodegradable Polymers with a Range of Applications. Journal of Chemical Technology and Biotechnology, 82, 233-247. http://dx.doi.org/10.1002/jctb.1667

[6] Albuquerque, M., Eiroa, M., Torres, C., Nunes, B. and Reis, M. (2007) Strategies for the Development of a Side Stream Process for Polyhydroxyalkanoate (PHA) Production from Sugar Cane Molasses. Journal of Biotechnology, 130, 411-421. http://dx.doi.org/10.1016/j.jbiotec.2007.05.011

[7] Keshavarz, T. and Roy, I. (2010) Polyhydroxyalkanoates: Bioplastics with a Green Agenda. Current Opinion in Microbiology, 13, 321-326. http://dx.doi.org/10.1016/j.mib.2010.02.006

[8] Valappil, S. P., Rai, R., Bucke, C. and Roy, I. (2008) Polyhydroxyalkanoate Biosynthesis in Bacillus cereus SPV under Varied Limiting Conditions and an Insight into the Biosynthetic Genes Involved. Journal of Applied Microbiology, 104, 1624-1635. http://dx.doi.org/10.1111/j.1365-2672.2007.03678.x

[9] Wang, Y., Hua, F., Tsang, Y., Chan, S., Sin, S., Chua, H., Yu, P. and Ren, N. (2007) Synthesis of PHAs from Waster under Various C:N Ratios. Bioresource Technology, 98, 1690-1693. http://dx.doi.org/10.1016/j.biortech.2006.05.039

[10] Johnson, K., Kleerebezem, R. and van Loosdrecht, M. (2010) Influence of the C/N Ratio on the perf5ormance of polyhydroxybutyrate (P(3HB)) Producing Sequencing Batch Reactors at Short SRTs. Water Research, 44, 52141-2152. http://dx.doi.org/10.1016/j.watres.2009.12.031

[11] Hong, K., Chen, G.Q., Yu, P.H.F., Zhang, G., Liu, Y. and Chua, H. (2000) Effect of C:N Molar Ratio on Monomer Composition of Polyhdroxyalk Anoates Produced by Pseudomonas mendocina 0806 and Pseudomonas pseudoalkaligenus YS1. Applied Biochemistry and Biotechnology, 84, 971-980. http://dx.doi.org/10.1385/ABAB:84-86:1-9:971

[12] Hartmann, R., Hany, R., Geiger, T., Egli, T., Witholt, B. and Zinn, M. (2004) Tailored Biosynthesis of Olefinic Medium-Chain-Length Poly $[(R)-3$-hydroxyalkanoates] in Pseudomonas putida GPo1 with Improved Thermal Properties. Macromolecules, 37, 6780-6785. http://dx.doi.org/10.1021/ma040035+

[13] Anderson, A.J. and Dawes, E.A. (1990) Occurrence, Metabolism, Metabolic Role and Industrial Uses of Bacterial Polyhydroxyalk Anoates. Microbiological Reviews, 54, 450-472.

[14] Wolf, O., Crank, M., Patel, M., Marscheider-Weidemann, F., Schleich, J., Hüsing, B. and Angerer, G. (2005) Techno-Economic Feasibility of Large-Scale Production of Bio-Based Polymers in Europe. European Communities.

[15] Akaraonye, E., Keshavarz, T. and Roy, I. (2010) Production of Polyhydroxyalkanoates: The Future Green Materials of Choice. Journal of Chemical Technology and Biotechnology, 85, 732-743. http://dx.doi.org/10.1002/jctb.2392

[16] Albuquerque, M., Torres, C. and Reis, M. (2010) Polyhydroxyalkanoate (PHA) Production by a Mixed Microbial Culture Using Sugar Molasses: Effect of the Influent Substrate Concentration on Culture Selection. Water Research, 44, 3419-3433. http://dx.doi.org/10.1016/j.watres.2010.03.021

[17] Omar, S., Rayes, A., Eqaab, A., VOß, I. and Steinbüchel, A. (2001) Optimization of Cell Growth and P3HB Accumulation on Date Syrup by a Bacillus megaterium Strain. Biotechnology Letters, 23, 1119-1123. http://dx.doi.org/10.1023/A:1010559800535

[18] Solaiman, D.K.Y., Ashby, R.D., Hotchkiss, A.T. and Foglia, T.A. (2006) Biosynthesis of Medium-Chain-Length Poly (hydroxyalkanoates) from Soy Molasses. Biotechnology Letters, 28, 157-162. http://dx.doi.org/10.1007/s10529-005-5329-2

[19] Nikel, P.I., De Almeida, A., Melillo, E.C., Galvagno, M.A. and Pettinari, M.J. (2006) New Recombinant Escherichia Coli Strain Tailored for the Production of Poly (3-hydroxybutyrate) from Agroindustrial By-Products. Applied and Environmental Microbiology, 72, 3949-3954. http://dx.doi.org/10.1128/AEM.00044-06

[20] Koller, M., Bona, R., Chiellini, E., Fernandes, E.G., Horvat, P., Kutschera, C., Hesse, P. and Braunegg, G. (2008) Polyhydroxyalkanoate Production from Whey by Pseudomonas hydrogenovora. Bioresource Technology, 99, 4854-4863. http://dx.doi.org/10.1016/j.biortech.2007.09.049

[21] Marangoni, C., Furigo, A. and de Aragão, G.M.F. (2002) Production of Poly(3-hydroxybutyrate-co-3-hydroxyvalerate) by Ralstonia eutropha in Whey and Inverted Sugar with Propionic Acid Feeding. Process Biochemistry, 38, 137-141. http://dx.doi.org/10.1016/S0032-9592(01)00313-2

[22] Van-Thuoc, D., Quillaguaman, J., Mamo, G. and Mattiasson, B. (2007) Utilization of Agricultural Residues for Poly (3-hydroxybutyrate) Production by Halomonas boliviensis LC1. Journal of Applied Microbiology, 104, 420-428. 
[23] Huang, T.Y., Duan, K.J., Huang, S.Y. and Chen, C.W. (2006) Production of Polyhydroxyalkanoates from Inexpensive Extruded Rice Bran and Starch by Haloferax mediterranei. Journal of Industrial Microbiology \& Biotechnology, 33, 701-706. http://dx.doi.org/10.1007/s10295-006-0098-z

[24] Halami, P.M. (2008) Production of Polyhydroxyalkanoate from Starch by the Native Isolate Bacillus cereus CFR06. World Journal of Microbiology and Biotechnology, 24, 805-812. http://dx.doi.org/10.1007/s11274-007-9543-z

[25] Haas, R., Jin, B. and Zepf, F.T. (2008) Production of Poly (3-hydroxybutyrate) from Waste Potato Starch. Bioscience, Biotechnology and Biochemistry, 72, 253-256. http://dx.doi.org/10.1271/bbb.70503

[26] Quillaguamán, J., Doan-Van, T., Guzmán, H., Guzmán, D., Martín, J., Everest, A. and Hatti-Kaul, R. (2008) Poly(3hydroxybutyrate) Production by Halomonas boliviensis in Fed-Batch Culture. Applied Microbiology and Biotechnology, 78, 227-232. http://dx.doi.org/10.1007/s00253-007-1297-x

[27] Kim, B.S. and Chang, H.N. (1998) Production of Poly (3-hydroxybutyrate) from Starch by Azotobacter chroococcum. Biotechnology Letters, 20, 109-112. http://dx.doi.org/10.1023/A:1005307903684

[28] Ribera, R.G., Monteoliva-Sanchez, M. and Ramos-Cormenzana, A. (2001) Production of Polyhidroxyalkanoates by Pseudomonas putida KT2442 Harboring pSK2665 in Wastewater from Olive Oil Mills (Alpechín). Electronic Journal of Biotechnology, 4, 11-12.

[29] Pozo, C., Martınez-Toledo, M., Rodelas, B. and Gonzalez-Lopez, J. (2002) Effects of Culture Conditions on the Production of Polyhydroxyalkanoates by Azotobacter chroococcum H23 in Media Containing a High Concentration of Alpechín (Wastewater from Olive Oil Mills) as Primary Carbon Source. Journal of Biotechnology, 97, 125-131. http://dx.doi.org/10.1016/S0168-1656(02)00056-1

[30] Bhubalan, K., Lee, W.H., Loo, C.Y., Yamamoto, T., Tsuge, T., Doi, Y. and Sudesh, K. (2008) Controlled Biosynthesis and Characterization of Poly(3-hydroxybutyrate-co-3-hydroxyvalerate-co-3-hydroxyhexanoate) from Mixtures of Palm Kernel Oil and 3HV-Precursors. Polymer Degradation and Stability, 93, 17-23. http://dx.doi.org/10.1016/j.polymdegradstab.2007.11.004

[31] Jiang, Y., Song, X., Gong, L., Li, P., Dai, C. and Shao, W. (2008) High Poly( $\beta$-hydroxybutyrate) Production by Pseudomonas fluorescens A2a5 from Inexpensive Substrates. Enzyme and Microbial Technology, 42, 167-172. http://dx.doi.org/10.1016/j.enzmictec.2007.09.003

[32] Yan, S., Tyagi, R. and Surampalli, R. (2006) Polyhydroxyalkanoates (PHA) Production Using Wastewater as Carbon Source and Activated Sludge as Microorganisms. Water Science and Technology, 53, 175-180.

http://dx.doi.org/10.2166/wst.2006.193

[33] Koller, M., Bona, R., Braunegg, G., Hermann, C., Horvat, P., Kroutil, M., Martinz, J., Neto, J., Pereira, L. and Varila, P. (2005) Production of Polyhydroxyalkanoates from Agricultural Waste and Surplus Materials. Biomacromolecules, 6, 561-565. http://dx.doi.org/10.1021/bm049478b

[34] Verlinden, R.A.J., Hill, D.J., Kenward, M.A., Williams, C.D., Piotrowska-Seget, Z. and Radecka, I.K. (2011) Production of Polyhydroxyalkanoates from Waste Frying Oil by Cupriavidus necator. AMB Express, 1, 1-8. http://dx.doi.org/10.1186/2191-0855-1-11

[35] Koutinas, A., Wang, R. and Webb, C. (2004) Restructuring Upstream Bioprocessing: Technological and Economic Aspects for Production of a Generic Microbial Feedstock from Wheat. Biotechnology and Bioengineering, 85, 524-538. http://dx.doi.org/10.1002/bit.10888

[36] Yu, J. and Stahl, H. (2008) Microbial Utilization and Biopolyester Synthesis of Bagasse Hydrolysates. Bioresource Technology, 99, 8042-8048. http://dx.doi.org/10.1016/j.biortech.2008.03.071

[37] Law, J.H. and Slepecky, R.A. (1961) Assay of Poly- $\beta$-hydroxybutyric Acid. Journal of Bacteriology, 82, 33-36.

[38] Dubois, M., Gilles, K.A., Hamilton, J.K., Rebers, P. and Smith, F. (1956) Colorimetric Method for Determination of Sugars and Related Substances. Analytical Chemistry, 28, 350-356. http://dx.doi.org/10.1021/ac60111a017

[39] Kjeldahl, J. (1883) A New Method for the Determination of Nitrogen in Organic Matter. Zeitschrift für Analytische Chemie, 22, 366-382. http://dx.doi.org/10.1007/BF01338151

[40] Kessler, B. and Witholt, B. (2001) Factors Involved in the Regulatory Network of Polyhydroxyalkanoate Metabolism. Journal of Biotechnology, 86, 97-104. http://dx.doi.org/10.1016/S0168-1656(00)00404-1

[41] Ersus, S. and Cam, M. (2007) Determination of Organic Acids, Total Phenolic Content and Antioxidant Capacity of Sour Citrus aurantium Fruit. Chemistry of Natural Compounds, 43, 607-609. http://dx.doi.org/10.1007/s10600-007-0203-1

[42] Ververis, C., Georghiou, K., Danielidis, D., Hatzinikolaou, D.G., Santas, R. and Corleti, V. (2007) Cellulose, Hemicelluloses, Lignin and Ash Content of Some Organic Materials and Their Suitability for Use as Paper Pulp Supplements. Bioresource Technology, 98, 296-301. http://dx.doi.org/10.1016/j.biortech.2006.01.007

[43] Taherzadeh, M.J. and Karimi, K. (2008) Pretreatment of Lignocellulosic Wastes to Improve Ethanol and Biogas Pro- 
duction: A Review. International Journal of Molecular Sciences, 9, 1621-1651. http://dx.doi.org/10.3390/ijms9091621

[44] De Aragao, G.M.F., Netto, W.S., Ienczak, J.L., Fiorese, M.L., Dalcaton, F., Schmidt, F., Deucher, R., Vecchi, C. and Rodrigues, R.C. (2008) Preparation of PHA (Polyhydroxyalkanoates) from a Citric Residue. Google Patents.

[45] Page, W.J. (1992) Production of Poly- $\beta$-hydroxybutyrate by Azotobacter vinelandii UWD in Media Containing Sugars and Complex Nitrogen Sources. Applied Microbiology and Biotechnology, 38, 117-121. http://dx.doi.org/10.1007/BF00169430

[46] Lee, S.Y. and Chang, H.N. (1994) Effect of Complex Nitrogen Source on the Synthesis and Accumulation of Poly (3-hydroxybutyric acid) by Recombinant Escherichia Coli in Flask and Fed-Batch Cultures. Journal of Environmental Polymer Degradation, 2, 169-176. http://dx.doi.org/10.1007/BF02067442

[47] Aldor, I.S. and Keasling, J.D. (2003) Process Design for Microbial Plastic Factories: Metabolic Engineering of Polyhydroxyalkanoates. Current Opinion in Biotechnology, 14, 475-483. http://dx.doi.org/10.1016/j.copbio.2003.09.002

[48] Reddy V.S., Thirumala, M. and Mahmood, S.K. (2009) Production of P(3HB) and P(3HB-co3HV) Biopolymers by Bacillus megaterium Strain OU303A Isolated from Municipal Sewage Sludge. World Journal of Microbiology and Biotechnology, 25, 391-397. http://dx.doi.org/10.1007/s11274-008-9903-3

[49] Tajima, K., Igari, T., Nishimura, D., Nakamura, M., Satoh, Y. and Munekata, M. (2003) Isolation and Characterization of Bacillus sp. INT005 Accumulating Polyhydroxyalkanoate (PHA) from Gas Field Soil. Journal of Bioscience and Bioengineering, 95, 77-81. http://dx.doi.org/10.1016/S1389-1723(03)80152-4

[50] Thirumala, M., Reddy, S.V. and Mahmood, S. (2010) Production and Characterization of P(3HB) from Two Novel Strains of Bacillus sp. Isolated from Soil and Activated Sludge. Journal of Industrial Microbiology \& Biotechnology, 37, 271-278. http://dx.doi.org/10.1007/s10295-009-0670-4

[51] Yilmaz, M. and Beyatli, Y. (2005) Poly-b-hydroxybutyrate (P(3HB)) Production by a Bacillus cereus M5 Strain in Sugar Beet Molasses. Zuckerindustrie, 130, 109-112.

[52] Khiyami, M.A., Al-Fadual, S.M. and Bahklia, A.H. (2011) Polyhydroxyalkanoates Production via Bacillus Plastic Composite Support (PCS) Biofilm and Date Palm Syrup. Journal of Medicinal Plant Research, 5, 3312-3320

[53] Ferreira-Leitao, V., Gottschalk, L.M.F., Ferrara, M.A., Nepomuceno, A.L., Molinari, H.B.C. and Bon, E.P.S. (2010) Biomass Residues in Brazil: Availability and Potential Uses. Waste and Biomass Valorization, 1, 65-76. http://dx.doi.org/10.1007/s12649-010-9008-8

[54] Erkut, Y. (2011) Turkey Citrus Annual Report, 2011. Global Agricultural Information Network, USDA Foreign Agricultural Service. 
Scientific Research Publishing (SCIRP) is one of the largest Open Access journal publishers. It is currently publishing more than 200 open access, online, peer-reviewed journals covering a wide range of academic disciplines. SCIRP serves the worldwide academic communities and contributes to the progress and application of science with its publication.

Other selected journals from SCIRP are listed as below. Submit your manuscript to us via either submit@scirp.org or Online Submission Portal.
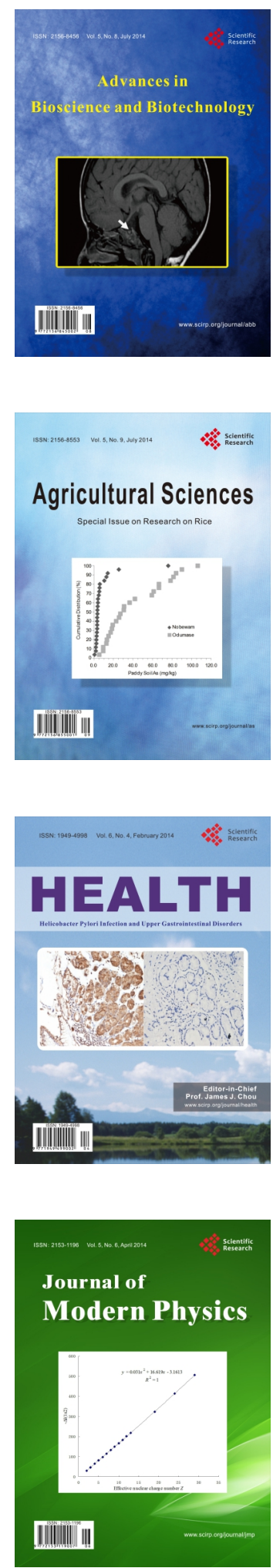
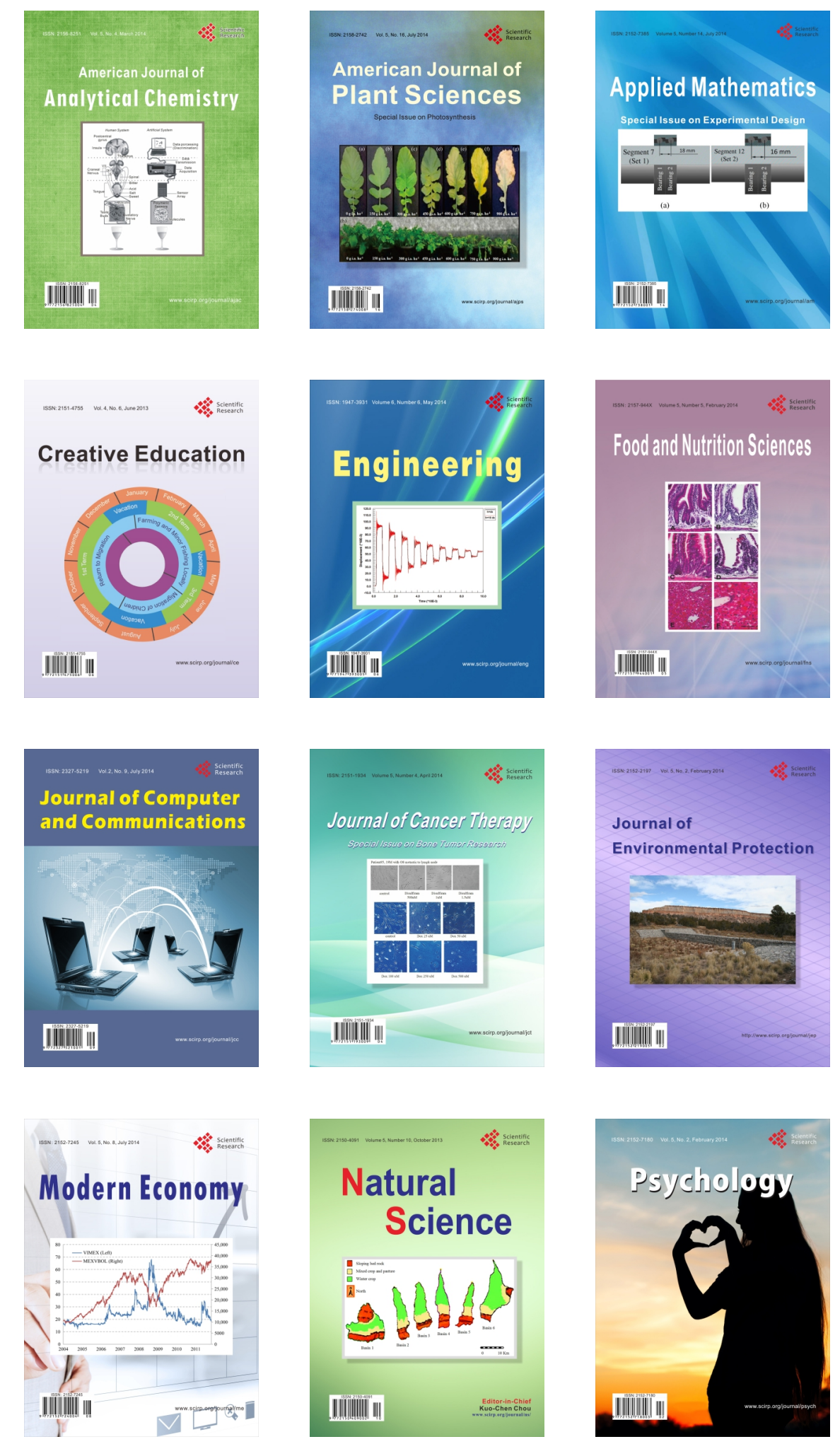